\title{
The Characteristics, Distribution and Management of Alfisols.
}

\author{
Demsew Bekele*and Muluadam Birhan \\ Bahir Dar University, College Of Agriculture and Environmental Sciences, Department of Natural Resource \\ Management, P.O.Box.5501, Bahir Dar, Ethiopia. \\ *Corresponding Authors: Demsew Bekele, Bahir Dar University, College Of Agriculture and \\ Environmental Sciences, Department of Natural Resource Management, P.O.Box.5501 , Bahir Dar , \\ Ethiopia.
}

\begin{abstract}
Alfisols are base-rich, timbered, mineral soils of sub-humid and humid regions. These are characterized by a light-colored surface horizon (ochricepipedon) over a clay enriched, argillic (Bt) subsurface horizon that is rich in exchangeable cationswith base saturation of more than 35\%. Alfisols from the soil science term Pedalfer implies aluminum and iron. Alfisols are forest soils that have relatively high native fertility. Alfisols typically exhibit well-developed, contrasting soil horizons (layers) depleted in calcium carbonate but enriched in aluminum-and iron-bearing minerals. Below the surface horizon lies a region with significant accumulation of translocated (migrated) layer silicate clay. This region, called the argillic horizon, is characterized by a relatively high content of available $c$ alcium, magnesium, potassium, and sodium ions.These soils have high native fertility. Kind of soil management causes changes in the soil characteristics and can affect agricultural yield. Physical and mineralogicalproperties of the soil proved an effective supplementary method for assessing correlations between the soil physical and mineralogical properties.
\end{abstract}

Keywords: Alfisols, management, sub-humid and humid

\section{INTRODUCTION}

Soil is a non-renewable dynamic naturalresourcewhich is very essential to sustain life on the earth surface (Schoonover and Crim, 2015).It is a loose unconsolidated material that constitutes mineral, organic matter and living organisms. It is also a three-phase dispersed system (solid, liquid and gaseous phases). It has physical, chemical, biological properties and activities that are necessary for ambitious crop production.Around the globe, many soil classifications systems have been developed to categorize soils into groups based on morphological and/ or chemical properties. The most widelyused classification system is the soil taxonomy system that was made known by the United States Department of Agriculture (USDA) (Baillie, 2001). This system is a morphogenetic system that utilizes both quantitative factors and soil genesis themes and assumptions to guide soil groupings (Boul et al. 1997; Balasubramanian, 2017).

About $10 \%$ of the land area of the planet is occupied by Alfisols, which because of natural fertility, location in humid and subhumid regions, and responsiveness to good management are widely used for agriculture and forestry. The central concept of Alfisols is that of forest soils that occupy relatively stable landscape positions and thus have a subsurface zone of clay accumulation (Boul et al., 2011).Most Alfisols have a udic, ustic, or xeric moisture regime, and many have aquic conditions. Alfisols are not known to have a perudic moisture regime. Leaching of bases from the soils may occur almost every year or may be infrequent (Baillie, 2001).

\section{DESCRIPTION OF ALFISOLS}

Alfisols from the soil science term Pedalfer implies aluminum and iron. Alfisols are forest soils that have relatively high native fertility. This native fertility, allows Alfisols to be very productive soils for agriculture. They tend to be more inherently fertile than Ultisols and are located in similar climatic regions, typically under forest vegetation. Alfisols are moderately leached soils typically found under hardwood forested areas or mixed vegetation areas which have average amounts of moisture. The parent material is mostly glacial. Leaf litter contributes greatly to fertility as a result is naturally productive soils and are good for varying agricultural uses. Alfisols have healthy, thin $\mathrm{O}$ and $\mathrm{A}$ 
horizons because they are generally formed under hardwood forests. Alfisols have a pronounced E horizon because of the eluviations of aluminum and iron suspended in clay particles. Alfisols are those soils have argillic horizon meaning, it has a "clay skin" or in the B horizon clay has accumulated. Alfisols may also have a fragipan, a duripan, a kandic horizon, a natric horizon, a petrocalcic horizon, plinthite, or other features, and these features are used in defining the great groups within the order (Baillie, 2001).

Alfisols that have a thermic or warmer soil temperature regime in areas of warm, humid climates. In regions of mesic and frigid soil temperature regimes, Alfisols are mostly on late-Pleistocene deposits or surfaces. In warmer regions, they are on late-Pleistocene or older surfaces if there are only infrequent years when the soils lose bases by leaching or if there is an external source of bases, such as calcareous dust from a desert.

Alfisols generally show extensive profile development, with distinct argillic (clay) accumulations in the subsoil. Extensive leaching often produces a light-colored E horizon below the topsoil. Generally fertile and productive, these soils typically have a high concentration of nutrient cations $(\mathrm{Ca}, \mathrm{Mg}, \mathrm{K}$, and $\mathrm{Na}$ ) and form in regions with sufficient moisture for plants for at least part of the year. These soils result from weathering processes. They leach clay minerals and other constituents out of the surface layer and into the subsoil where they can retain and supply moisture and nutrients to plants. They are deep, have high nutrient capital, are not acid and are therefore of generally high fertility. Alfisols in tropical Africa are increasingly threatened bynutrient depletion (Sanchez and Swaminathan 2005; Sanchez 2002), more frequentdroughts in Southern Africa, and more intenseerosion caused by increasingly erraticrainfall variability(Baillie, 2001).

\section{Distribution OF AlFiSOLS}

Alfisols are prevalent in 5 of the 13 biomes: flooded grasslands and savannas, temperate broad-leaved and mixed forests, tropical/subtropical dry broadleaved forests, tropical/subtropical coniferous Forests and Mediterranean biomes (Sanchez and Swaminathan 2005). Alfisols occur under a wide range of environmental conditions and are found in temperate, tropical, and boreal regions of the world. Alfisols are found in cool to hot humid areas, and in the semiarid tropics; they are formed mostly under forest vegetation, but also under grass savanna. Extensive areas of Alfisols are found in the farmlands in previously forested parts of mid western North America, Europe, and Russia, as well as much of sub-humid and semiarid tropical Africa and India. Most often, Alfisols develop under native deciduous forests, although in some cases, as in California and parts of Africa, savanna (mixed trees and grass) is the native vegetation. They are prominent across the southern lower peninsular and the Western UP. Much of Michigan's most productive agriculture lands are Alfisols. They are relatively common and cover roughly $10 \%$ of earths non-ice covered surface.Alfisols make up about $14 \%$ of US soils and formed either from glacial parent material or under mixed vegetation (Baillie, 2001).

\subsection{Association of Alfisols with other reference soil groups}

\subsubsection{Limitations between Alfisols and Other Soil Orders}

The definition of Alfisols must provide criteria that separate Alfisols from all other orders. The aggregate of these criteria defines the limits of Alfisols in relation to all other known soils. Alfisols are more strongly weathered than other soil orders, but less weathered than Spodosols and Ultisols. Natural fertility and productive capacity of Alfisols is considered to be greater than that of Ultisols, but less than that of Mollisols (Baillie, 2001).

\section{Alfisols are mineral soils that meet all of the following:}

1. Unlike Histosols, Alfisols do not have organic soil materials that meet one or more of the following:

(a). Overlie cindery, fragmental, materials and fill their interstices and directly below these materials have either a densic, lithic, or paralithic contact; or(b). When added with the underlying cindery, fragmental, total $40 \mathrm{~cm}$ or more between the soil surface and a depth of $50 \mathrm{~cm}$; or(c).Constitute twothirds or more of the total thickness of the soil to a densic, lithic, or paralithic contact and have no mineral horizons or have mineral horizons with a total thickness of $10 \mathrm{~cm}$ or less; or(d). Are saturated with water for 30 days or more in normal years (or are artificially drained), have an upper boundary within $40 \mathrm{~cm}$ of the soil surface, and have a total thickness of either: 
(1) $60 \mathrm{~cm}$ or more if three-fourths or more of their volume consists of moss fibers or if their bulk density, moist, is less than $0.1 \mathrm{~g} / \mathrm{cm} 3$; or

(2) $40 \mathrm{~cm}$ or more if they consist either of sapric or hemic materials, or of fibric materials with less than three-fourths (by volume) moss fibers and a bulk density, moist, of $0.1 \mathrm{~g} / \mathrm{cm} 3$ or more;

2. Unlike Spodosols, Alfisols do not have a spodic horizon or an Ap horizon containing 85 percent or more spodic materials above the argillic, kandic, or natric horizon and do not have one or more of the following:

(a). An albic horizon in 50 percent or more of each pedon and a cryic soil temperature regime; or(b). A spodic horizon with all of the following characteristics:

(1) One or more of the following:

(a) A thickness of $10 \mathrm{~cm}$ or more; or(b) An overlying Ap horizon; or(c) Cementation in 50 percent or more of each pedon; or(d) A coarse-loamy, loamy-skeletal, or finer particle-size class and a frigid soil temperature regime; or(e) A cryic soil temperature regime; and

(2) An upper boundary within the following depths from the mineral soil surface: either

(a) Less than $50 \mathrm{~cm}$; or(b) Less than $200 \mathrm{~cm}$ if the soil has a sandy particlesize class between the mineral soil surface and the spodic horizon; and

(3) A lower boundary as follows:

(a) Either at a depth of $25 \mathrm{~cm}$ or more below the mineral soil surface or at the top of a duripan or fragipan or at a densic, lithic, paralithic, or petroferric contact, whichever is shallowest; or(b) At any depth if the spodic horizon has a coarseloamy, loamy-skeletal, or finer particle-size class and the soil has a frigid temperature regime, or if the soil has a cryic temperature regime;

3. Unlike Andisols, Alfisols have andic soil properties in less than 60 percent of the thickness either:

(a). Within $60 \mathrm{~cm}$ of either the mineral soil surface or of the top of an organic layer with andic soil properties, whichever is shallower, if there is no densic, lithic, or paralithic contact, duripan,or petrocalcic horizon within that depth; or (b). Between either the mineral soil surface or the top of an organic layer with andic soil properties, whichever is shallower, and a densic, lithic, or paralithic contact, a duripan, or a petrocalcic horizon;

4. Unlike Gelisols, Alfisols do not have:

(a). Permafrost within $100 \mathrm{~cm}$ of the soil surface; or (b). Gelic materials within $100 \mathrm{~cm}$ of the soil surface and permafrost within $200 \mathrm{~cm}$ of the soil surface;

5. Unlike Oxisols, Alfisols do not have:

(a). An oxic horizon that has its upper boundary within $150 \mathrm{~cm}$ of the mineral soil surface, unless the soil also has both an argillic or kandic horizon that has its upper boundary within that depth and less than 40 percent (by weight) clay in the fine-earth fraction between the mineral soil surface and a depth of $18 \mathrm{~cm}$ (after mixing) or more than 10 percent weatherable minerals; and (b). Both of the following:

(1) A kandic horizon that has less than 10 percent weatherable minerals and has an upper boundary within $150 \mathrm{~cm}$ of the mineral soil surface and

(2) 40 percent or more (by weight) clay in the fine-earth fraction between the mineral soil surface and a depth of $18 \mathrm{~cm}$ (after mixing);

6. Unlike Vertisols, Alfisols do not have all of the following:

(a). A layer $25 \mathrm{~cm}$ or more thick, with an upper boundarywithin $100 \mathrm{~cm}$ of the mineral soil surface, that has either slickensides close enough to intersect or wedge-shaped aggregates that have their long axes tilted 10 to 60 degrees from the horizontal; and (b). A weighted average of 30 percent or more clay in the fine-earth fraction either between the mineral soil surface and a depth of $18 \mathrm{~cm}$ or in an Ap horizon, whichever is thicker, and 30 percent or more clay in the fine-earth fraction of all horizons between a depth of $18 \mathrm{~cm}$ and either a depth of $50 \mathrm{~cm}$ or a densic, lithic, or paralithic contact, a duripan, or a petrocalcic horizon if shallower; and (c). Cracks that open and close periodically; 
7. Unlike Aridisols, Alfisols do not have an aridic soil moisture regime;

8. Unlike Ultisols, Alfisols have either:

(I). An argillic or kandic horizon, but no fragipan, and a base saturation (by sum of cations) of 35 percent or more at one of the following depths:

(1) In an epipedon that has a sandy or sandy-skeletal particle-size class throughout, either:

(a) $125 \mathrm{~cm}$ below the upper boundary of the argillic or kandic horizon (but no deeper than $200 \mathrm{~cm}$ below the mineral soil surface) or $180 \mathrm{~cm}$ below the mineral soil surface, whichever is deeper; or(b) At a densic, lithic, paralithic, or petroferric contact if shallower; or

(2) The shallowest of the following depths:

(a) $125 \mathrm{~cm}$ below the upper boundary of the argillic or kandic horizon; or(b) $180 \mathrm{~cm}$ below the mineral soil surface; or(c) At a densic, lithic, paralithic, or petroferric contact; or

(II). A fragipan and a base saturation (by sum of cations) of 35 percent or more at the shallowest of the following depths:

(a) $75 \mathrm{~cm}$ below the upper boundary of the fragipan; or (b) $200 \mathrm{~cm}$ below the mineral soil surface; or (c) At a densic, lithic, paralithic, or petroferric contact;

9. Unlike Mollisols, Alfisols do not have both:

(a). A mollic epipedon or both a surface horizon that meets all of the requirements for a mollic epipedon except thickness after the surface soil has been mixed to a depth of $18 \mathrm{~cm}$, and a subhorizon more than $7.5 \mathrm{~cm}$ thick, within the upper part of an argillic, kandic, or natric horizon, that meets the color, organic-carbon content, base saturation, and structure requirements of a mollic epipedon but is separated from the surface horizon by an albic horizon; and

(b). A base saturation of 50 percent or more (by NH4OAc) in all horizons either between the upper boundary of any argillic, kandic, or natric horizon and a depth of $125 \mathrm{~cm}$ below that boundary, or between the mineral soil surface and a depth of $180 \mathrm{~cm}$, or between the mineral soil surface and a densic, lithic, or paralithic contact, whichever depth is shallowest;

10. Unlike Inceptisols and Entisols, Alfisols have either: (a). An argillic, kandic, or natric horizon; or (b). A fragipan that has clay films $1 \mathrm{~mm}$ or more thick in some part (Baillie, 2001).

\section{GENESIS/FORMATION OF ALFISOLS}

Alfisols may be formed from different parent materials, including clayey till (Badriver series), loess of varying thickness (the Dubuque $76 \mathrm{~cm}$ and Magnor, Sherry, Valton and Ozaukee series $<56 \mathrm{~cm}$ ), and sandy outwash. Alfisols form in loamy parent materials that are not too sandy or too clayey under semiarid tohumid areas, typically under hardwood forest cover vegetation. These soils are well developed and contain a subsurface horizon in which clays have accumulated.

\section{Properties of Alfisols}

\subsection{Morphological properties}

The morphological characteristics of the soil includes soil depth. The variation in soil depth is most likely attributed to the variation in micro- relief and slope that influence soil formation and development through its effects on erosion and infiltration. However, argillic B-horizons were well developed in alfisols (Gebrekidan, 2001)

Alfisols has dominant soil color changes from gray to a gray-brown, because of the change in the dominant type of natural vegetation from a pine to a deciduous or broad-leaved forest a combination of oak, beech, and hickory. Alfisols characterized by accumulations of clay in the B horizon, but the longer growing season and the deciduous vegetation results in a generally more productive soil. (http://geo.msu.edu/extra/geogmich/ alfisols.html).

\subsection{Mineralogical Properties}

Mineralogical composition of the clay fractions of Alfisol profiles developed on gneissic rocks. Both the silt and clay fractions are kaolin tic and contain considerable amorphous material (Murali et al., 1974).

\subsection{Hydrological Properties}

Alfisols, the most abundant soils in the semiarid tropics, cover nearly $33 \%$ of this region. They have sufficient moisture for plants for at least part of the year (Pathak and Sahrawat, 2013). A very few 
Alfisols that are very wet during part of the year have an umbric epipedon and have moderate to high base saturation and in which water is held at less than $1500 \mathrm{kPa}$ tension during at least 3 months each year when the soils are warm enough for plants to grow (Baillie, 2001). To develop appropriate and more effective soil and water management strategies and practices, a better understanding of the hydrological behavior of soils is extremely important (Pathak and Sahrawat, 2013).

\subsection{Physical properties}

Texture is an intrinsic soil property, but intensive cultivation contributed to the variations in particle size distribution at the surface horizons of the cultivated and the abandoned lands. Alfisols topsoil texture varies, and clay mineralogy is mixed with both permanent and variable charged clays (Gebrekidan, 2001). Alfisols characterized by a light-coloured surface horizon (ochricepipedon) over clay enriched, argillic (Bt) sub-surface horizon (Vipinet al, 2016).

\subsection{Chemical properties}

Alfisols are timbered, mineral soils of sub-humid and humid regions whichhave a high concentration of nutrient cations $(\mathrm{Ca}, \mathrm{Mg}, \mathrm{K}$, and $\mathrm{Na}$ ), base-rich, with base saturation of more than $35 \%$, less acidic, high fertility. They are generally fertile and productive soils(Vipinet al, 2016). In addition, base-rich parent materials or less-intense weathering and leaching regimes have resulted in subsoils that contain relatively abundant supplies of exchangeable calcium, magnesium, potassium, and accumulation of silicate clays (argillic) horizon (Boul et al. , 2011).The soil $\mathrm{pH}\left(\mathrm{H}_{2} \mathrm{O}\right)$ of Alfisols consistently increased in the abandoned land whereas decreased in the virgin land with increasing profile depth. ThepH $\left(\mathrm{H}_{2} \mathrm{O}\right)$ of Alfisols significantly increases down to the soil profile in the cultivated lands. The highest and the lowest were recorded at the surface horizons of the virgin and the cultivated lands, respectively (Gebrekidan, 2001) Alfisols has also higher organic carbon in thesurface horizon as a result of increased organic matterinputs and its decomposition (Groenendijk et al, 2002, Samndi and Jibrin, 2012).

\section{Classification of Alfisols}

Classification of soil is the separation of soil into classes or groups each having similar characteristics and potentially similar behavior. Alfisols generally fall under the classification of an ochric epipedon, meaning they are lower in organic content.The central concept of Alfisols is that of soils that have an argillic, a kandic, or a natric horizon and a base saturation of 35\% or greater. They typically have an ochric epipedon, but may have an umbric epipedon. They may also have a petrocalcic horizon, a fragipan or a duripan.

\section{Management AND USE OF Alfisols}

Alfisols are important for agriculture, grazing, forestry, and urbanization. Many of the most productive agricultural soils in the state are Alfisols, especially in the Hapludalfs great group. Similarly, some of the most productive forest soils for hardwood sawlogs, veneer, and maple syrup production are Hapludalfs, including the Bertrand, Emmet, Fayette, Gale, Hixton, La Farge, McHenry, Seaton, and Theresa soil series(Bockheim and Hartemink, 2017). In northern Wisconsin, some of the Glossudalfs, including the Amery, Antigo, Cushing, Kennan, Otterholt, and Withee soil series, are highly productive for forest products. Seven of the 10 most populated cities in Wis- consin, accounting for 1.2 million persons, occur within a Hapludalfs soil-map unit .The Antigo silt loam (Haplic Glossudalfs) was selected as the state soil because of its importance in agriculture, grazing, and forestry (Balasubramanian, 2017).

\section{CONCLUSiON}

Classification is basically important to any science. Classification provides the avenue through which research can be addressed in a rigorously systematic manner. Classifications also have more practical applications. Classification of soils is necessary for all soil survey program and mapping the soils of any region. Classification of soil is the separation of soil into classes or groups each having similar characteristics and potentially similar behavior. Alfisols generally fall under the classification of an ochric epipedon, meaning they are lower in organic content. Soil surveys employ the principles, functions of soil science to agriculture, forestry and engineering to predict soil behavior for different use, management or manipulation.

\section{ACKNOWLEDGEMENT}

The authors acknowledges Generally Bahir Dar University, College Of Agriculture and Environmental Sciences, Department of Natural Resource Management. I would like to express my 
sincere gratitude and appreciation to Prof. YihenewG.Selassieand Dr EyayuMollafor theirexcellent guidance and support throughout my Academic life.

\section{REFERENCES}

[1] Baillie, I. C. (2001). Soil Survey Staff 1999, Soil Taxonomy: A basic system of soil classification for making and interpreting soil surveys, Agricultural Handbook 436, Natural Resources Conservation Service, USDA, Washington DC, USA, pp. 869. Soil Use and management, 17(1), 57-60.

[2] Balasubramanian, V., Ragunath, K. P., Mugilan, G. R., \& Pazhanivelan, S. Characterization and classification of soils of Veerapandi block of Salem district of Tamil Nadu-South India.

[3] Bockheim, J. G., \& Hartemink, A. E. (2017). Alfisols. In The Soils of Wisconsin (pp. 129-147). Springer, Cham.

[4] Boul, S. W., Hole, F. D., McCRACKEN, R. J., \& Southard, R. J. (1997). Soil genesis and classification. Ames.

[5] Buol, S. W., Southard, R. J., Graham, R. C., \& McDaniel, P. A. (2011). Soil genesis and classification. John Wiley \& Sons.

[6] FAO, 2006. World reference base for soil resources. World Soil Resources Vaile delle Terme di Caracalla Rome, Italy

[7] Gebrekidan Wakene, and N. H. (2001). The Impact of Different Land Use System on Soil Quality of Western Ethiopian Alfisols. 1-7.

[8] Groenendijk, F. M., Condron, L. M., \& Rijkse, W. C. (2002). Effects of afforestation on organic carbon, nitrogen and sulfur concentrations in New Zealand hill country soils. Geoderma, 108(1-2), 91-100.

[9] John E.Schoonover and Jackie F.Crim.2015.Anintroduction to soil concepts and the role of soils in watershed management, water research and education,154:21-47.

[10] Krasilnikov, P., Martí, J. J. I., Arnold, R., \& Shoba, S. (2009). A handbook of soil terminology, correlation and classification. Routledge.

[11] MSU. Department of agriculture,https://www.goe.msu.edu/extra/geogmich/alfisols.html, Accessed on Novmember24, 2019.

[12] Murali, V., Sarma, V. A. K., \& Murti, G. K. (1974). Mineralogy of two red soil (Alfisol) profiles of Mysore State, India. Geoderma, 11(2), 147-155.

[13] Nachtergaele, F. (2001). Soil taxonomy---a basic system of soil classification for making and interpreting soil surveys. Geofisica Internacional, 99, 336-337.

[14] Pathak, P., Sudi, R., Wani, S. P., \& Sahrawat, K. L. (2013). Hydrological behavior of Alfisols and Vertisols in the semi-arid zone: Implications for soil and water management. Agricultural Water Management, 118, 12-21.

[15] Plant and soil science e library, 2019.Soil genesis and development, lesson 5 soil classification and morphology, https://www.passel2.unl.edu/, Accessed on Novmember14, 2019.

[16] Samndi, A. M., \& Jibrin, J. M. (2012). Pedogenesis and classification of soils under teak (Tectona grandis Linn. f) plantation of various ages in the southern Guinea savanna of Nigeria. Asian Journal of Agricultural Sciences, 4(1), 16-25.

[17] Sanchez, P. A. (2002). Soil fertility and hunger in Africa. Science, 295(5562), 2019-2020.

[18] Sanchez, P. A., \& Swaminathan, M. S. (2005). Hunger in Africa: the link between unhealthy people and unhealthy soils. The Lancet, 365(9457), 442-444.

[19] Veloo, R., Paramananthan, S., \& Van Ranst, E. (2014). Classification of tropical lowland peats revisited: The case of Sarawak. Catena, 118, 179-185.

[20] Vipin, K., Surya, K., \& Achin, K. (2016). Morphological and pedological features of Alfisols. Agriways, 4(2), 159-167.

Citation: Demsew Bekele*and Muluadam Birhan, (2021). "The Characteristics, Distribution and Management of Alfisols. ", International Journal of Research Studies in Agricultural Sciences (IJRSAS), 7(6), pp. 1-6 DOI: http://dx.doi.org/10.20431/2454-6224.0706001

Copyright: (C) 2021 Authors. This is an open-access article distributed under the terms of the Creative Commons Attribution License, which permits unrestricted use, distribution, and reproduction in any medium, provided the original author and source are credited. 